\title{
Effect of dietary utilization of seed meal of cooked African locust bean (Parkia biglobosa) in Broiler Chickens
}

\author{
M. S. Tamburawa ${ }^{1 *}$, S. O. Ogundipe ${ }^{2}$, T. S. B. Tegbe ${ }^{2}$ and T. S. Olugbemi ${ }^{2}$ \\ ${ }^{1}$ Animal Science Department, Kano University of Science and Technology, Wudil, Nigeria. \\ ${ }^{2}$ Animal Science Department, Ahmadu Bello University Zaria, Samaru, Nigeria. \\ ${ }^{*}$ Corresponding author. Email: muazutambura@gmail.com
}

Copyright (@ 2016 Tamburawa et al. This article remains permanently open access under the terms of the Creative Commons Attribution License 4.0, which permits unrestricted use, distribution, and reproduction in any medium, provided the original work is properly cited.

Received 1st November, 2016; Accepted 10th December, 2016

\begin{abstract}
Present study was conducted to ascertain the effect of cooked African locust bean seed meal (CALBSM) diets on the growth response, organs weights and carcass characteristics of broiler chickens. Two hundred and twenty five day old broiler chickens (Marshall strain) were fed with diets containing CALBSM at dietary level 0, 7.5, 15, 22.5 and $30 \%$, designated as Treatment 1, 2, 3,4 and 5.. Diets were allocated with three replicates $(n=45)$ to experimental animals in a completely randomized design (CRD). The experiment lasted 9 weeks (4 weeks for initial phase, 1 week adjustment period and 4 weeks final phase). The results of growth response at initial phase showed significant differences $(P<0.05)$ in final body weight $(977.00$ to $1194.33 \mathrm{~g})$, total feed intake (1853.51 to $1905.96 \mathrm{~g})$ and feed conversion ratio (1.63 to 1.79). The highest weight gain and better performance were recorded in chicks fed with $15 \%$ CALBSM based diets compared to others. Similarly, the performance of broiler chicken at final phase showed the significant differences $(P<0.05)$ in the final body weight $(2585.75$ to $2976.69 \mathrm{~g})$, total weight gain of chicks $(957.70$ to $1369.70 \mathrm{~g}$ ) and feed cost per weight gain (181.32 to $239.27 \mathrm{~A} / \mathrm{kg}$ gain). Higher weight gains in all phases were recorded for broiler chickens fed 15\% CALBSM based diet compared to others. Carcass weight (1661.24 to $2020.51 \mathrm{~g})$ and dressing percentages $(69.88$ to $73.20 \%)$ were significantly $(P<0.05)$ higher in chicks fed $15 \%$ CALBSM diet over others. Breast muscle $(17.79$ to $22.27 \%)$, thigh and drumstick $(16.78$ to $19.84 \%)$ were significantly $(P<0.05)$ affected by the dietary treatments. Results indicates that most of the organs (heart, lungs, pancreas and kidney) weight but liver did not show significant differences $(P<0.05)$. However, there were significant differences $(P<0.05)$ in the weight of gizzards and small intestines. Present findings lead authors to conclude that African locust bean seed meal cooked for 4 hours could be included in the diet of broiler chickens up 15\% dietary level without any adverse effect on growth response, organs weights and carcass characteristics.
\end{abstract}

Key words: Broiler chickens, locust bean seeds, growth response, carcass weights.

\section{INTRODUCTION}

Feed is the most important input in a profitable poultry production. It accounts for 70 to $80 \%$ of the total production cost (Ogundipe, 1987 and Kehinde et al., 2006). At present, the high cost of conventional feedstuffs has brought about the need to have alternative feedstuffs that can replace the expensive ones to reduce the cost of livestock production (Longe, 2006 and Bamgbose et al.,
2011). The use of unconventional feed ingredients in compounding poultry feed in order to reduce cost of production is well documented in literature (Abeke, 2008; Duru, 2010). Non conventional feedstuffs offer the best alternatives in our environment for reducing feed cost and therefore a reduction in the cost of meat and animal products (Dafwang et al., 2001). 
Table 1. Proximate composition of raw and differently cooked African locust bean seeds for different durations.

\begin{tabular}{lccccc}
\hline \multirow{2}{*}{ Parameters } & \multicolumn{5}{c}{ Cooked African bean seed meal } \\
\cline { 2 - 6 } & Raw & 1 hour & 2 hours & 3 hour & 4 hours \\
\hline Dry matter (\%) & 96.36 & 95.40 & 93.33 & 96.02 & 94.53 \\
Crude Protein (\%) & 24.31 & 24.68 & 26.25 & 27.76 & 29.91 \\
Crude fibre (\%) & 13.55 & 13.52 & 7.34 & 6.33 & 5.03 \\
Ether extract (\%) & 4.97 & 3.15 & 3.19 & 3.14 & 3.18 \\
Ash (\%) & 4.85 & 3.15 & 7.33 & 9.35 & 8.24 \\
NFE (\%) & 52.75 & 55.26 & 54.65 & 53.47 & 53.69 \\
\hline
\end{tabular}

The search for alternative sources of protein from legume crops in lieu of expensive ones has been advocated (Adebowale and Lawal, 2004). The African locust bean tree is a leguminous plant which produces seed grain that is often cheaper and readily available in northern Nigeria. It grows in the savannah region of Nigeria, to the southern edge of Sahel zone (Oyenuga, 1968; Campbell-Platt, 1980). African locust bean seed is rich in protein and is used as a flavor intensifier for soups and stew (Dike and Odunfa, 2003). Protein content of seeds varies between 25 to $30 \%$ and has the potential to be utilized in livestock feeding (Olomu, 2011). The objective of this study was to determine the effect of cooked African locust bean meal diets on growth response, organs and carcass characteristics in broilers chickens.

\section{MATERIALS AND METHODS}

\section{Experimental site}

Experiment was conducted at the Teaching and Research Farm of the Department of Animal Science, Faculty of Agriculture and Agricultural Technology, Kano University of Science and Technology, Wudil. It is located in the Sudan savannah region of Nigeria. The farm is located on latitude $11^{\circ} 37^{\prime} \mathrm{N}$ and longitude $8^{\circ} 58^{\prime} \mathrm{E}$ at an altitude of $403 \mathrm{~m}$ above sea level. The annual rainfall ranges from 850 to $870 \mathrm{~mm}$, while minimum and maximum temperature ranges between 26 and $33^{\circ} \mathrm{C}$. The relative humidity of the region is always low and ranges between, 40 to $51.3 \%$ (Olofin et al., 2008).

\section{Processing of African locust bean seeds}

Samples of the seeds were cooked for different time periods (1, 2, 3 and 4 hours) at the rate of $1 \mathrm{Kg}$ per 8 litres of portable water. The beans were washed and then poured into a pot containing boiled water at a temperature of $100^{\circ} \mathrm{C}$. Samples of cooked African locust beans were then removed within the intervals of each one hour, while the heating of boiling water was continuously applied. The samples taken at hourly intervals were then allowed to cool, spread and sun dried in aluminium metal trays for 3 days. These cooked seeds were then subjected to laboratory analysis for proximate composition according to AOAC (1990). The proximate composition of differently cooked seeds is presented in Table 1. The composition indicated that seeds cooked for 4 hours gave better crude protein compared to the raw and other cooked seeds $(29.91 \%$ CP). Similarly the crude fibre $(5.03 \% \mathrm{CF})$ content of cooked seeds was slightly reduced compared to raw seeds. This gave the basis for chosen African locust bean seed cooked for 4 hours as our best processing methods by cooking.

\section{Experimental diets}

Five broiler diets (Starter and finisher) were formulated and compounded containing African locust bean seeds meal cooked four hours at dietary level $0,7.5,15,22.5$ and $30 \%$ designated as Treatment 1, 2, 3, 4 and 5 . The large quantity of locust bean seed was cooked for four hours and excess water was drained and allowed to sun dry for 3 days. After sun drying, seed were milled and incorporated in broiler finisher diets. The composition of broiler starter and finisher diets are presented in Table 2 and 3 . The diets were isonitrogenous and isocarloric according the nutrient requirement of the birds (NRC, 1994).

\section{Experimental animals and design}

Two hundred and twenty-five day old broiler chickens (Marshall strain) were fed diets containing cooked African locust bean seeds meal (CALBSM) at dietary level 0, 7.5, $15,22.5$ and $30 \%$ designated as Treatment 1, 2, 3,4 and 5. Diets were allocated to birds in a completely randomized design (CRD. Each treatment was replicated 3 times containing 15 birds making 45 per treatment. The 
Table 2. Composition of experimental diets for broiler starter containing graded levels of cooked African locust bean seed meal (CKALBSM).

\begin{tabular}{|c|c|c|c|c|c|}
\hline \multirow{3}{*}{ Ingredients (\%) } & \multicolumn{5}{|c|}{$\%$ Levels of inclusion of cooked ALBSM } \\
\hline & T1 & T2 & T3 & T4 & T5 \\
\hline & $(0 \%)$ & $(7.5 \%)$ & $(15 \%)$ & $(22.5 \%)$ & $(30 \%)$ \\
\hline Maize & 53.00 & 49.50 & 46.50 & 43.50 & 40.40 \\
\hline Groundnut cake & 25.00 & 21.00 & 16.50 & 12.00 & 7.60 \\
\hline Cooked ALBSM & 0.00 & 7.50 & 15.00 & 22.50 & 30.00 \\
\hline Soya bean Full-fat & 10.00 & 10.00 & 10.00 & 10.00 & 10.00 \\
\hline Fish meal & 3.00 & 3.00 & 3.00 & 3.00 & 3.00 \\
\hline Wheat offal & 5.00 & 5.00 & 5.00 & 5.00 & 5.00 \\
\hline Bone meal & 3.00 & 3.00 & 3.00 & 3.00 & 3.00 \\
\hline Salt & 0.30 & 0.30 & 0.30 & 0.30 & 0.30 \\
\hline Lysine & 0.20 & 0.20 & 0.20 & 0.20 & 0.20 \\
\hline Methionine & 0.25 & 0.25 & 0.25 & 0.25 & 0.25 \\
\hline \multirow[t]{2}{*}{ Vitamin-mineral premix ${ }^{*}$} & 0.25 & 0.25 & 0.25 & 0.25 & 0.25 \\
\hline & 100 & 100 & 100 & 100 & 100 \\
\hline \multicolumn{6}{|l|}{ Calculated analysis (\%) } \\
\hline Crude protein & 23.00 & 23.00 & 23.00 & 23.00 & 23.00 \\
\hline M. E.(Kcal/kg) & 2944 & 2945 & 2949 & 2954 & 2957 \\
\hline Crude fibre & 3.34 & 3.45 & 3.54 & 3.63 & 3.73 \\
\hline Ether extract & 5.85 & 5.71 & 5.54 & 5.41 & 5.25 \\
\hline Ash & 3.36 & 4.16 & 4.14 & 5.72 & 6.51 \\
\hline $\mathrm{Ca}$ & 1.36 & 1.37 & 1.38 & 1.39 & 1.39 \\
\hline$P$ & 0.95 & 0.94 & 0.92 & 0.92 & 0.90 \\
\hline Lysine & 1.21 & 1.25 & 1.28 & 1.31 & 1.31 \\
\hline Methionine+ cystine & 0.58 & 0.62 & 0.65 & 0.69 & 0.72 \\
\hline Feed Cost $\mathrm{N} / \mathrm{kg}$ & 76.06 & 75.26 & 74.36 & 73.46 & 72.58 \\
\hline
\end{tabular}

*Biomix premix supplied the following per kg of diet: Vit. A, 10000 I.U., Vit. D, 2000 i.u;Vit k,2mg Vit.B1(Thiamine), 1.8mg; Vit B2 (Riboflavin), 5.5mg; Vit B6 (Pyridoxine), 0.3mg; Vit B12, 0.015mg; Pantothenic acid, 7.5mg; Folic acid, 0.75mg; Niacin, 27.5mg; Biotin, 0.6mg; Choline chloride, 300mg; Cobalt, 0.2mg; copper, 3mg; lodine, 1mg; Iron, 20mg; manganese, 40mg; Selenium, 0.2mg; Zinc, 30mg; Antioxidant, 1.25mg.

experiment lasted 9 weeks (4 weeks for starter phase, 1 week adjustment period and 4 weeks finisher phase). Fifteen birds were allocated to a pen measuring $2.10 \mathrm{~m}$ length, $2.10 \mathrm{~m}$ wide and $1.25 \mathrm{~m}$ height. The pens were constructed with wood and wire mesh. Wood shavings were properly spread on the floor of each pen to avoid feacal contamination.

\section{Data Collection}

Birds were weighed at the beginning of the experiment for the initial body weights in an emptied plastic container using $10 \mathrm{~kg}$ weighing scale. Subsequently, broilers were re-weighed on weekly basis to determine the weight gain of the birds fed with different diets. A known quantity of feed was offered daily and the feed consumed by birds was determined by subtracting a leftover from the quantity of feed allocated to chicks every day. The feed conversion ratio was calculated as ratio of daily feed consumed to daily weight gain. At the end experiment, the final body weights of birds were also taken and the initial body weight was subtracted from the final body weight to calculate the total weight gain of birds within the period of the experiment.

At the end of the experiment, carcass analysis was carried out in which three birds from each replicate were randomly chosen and starved for 24 hours before slaughtering. The final live weights of birds were recorded before slaughtering. The birds were bled by slaughtering, immersed in hot water, defeathered and eviscerated. Carcass weights and meat cut parts (back, drumstick, thigh and wings) were weighed. All the values obtained were expressed as percentage of the live weight of birds. Similarly, the gut weights (weights of crop, proventriclus, gizzard, small intestine and large intestine) were 
Table 3. Composition of broiler finisher diets containing graded levels of cooked African locust bean seed meal (CALBSM).

\begin{tabular}{|c|c|c|c|c|c|}
\hline \multirow{3}{*}{ Ingredients (\%) } & \multicolumn{5}{|c|}{ Levels of inclusion } \\
\hline & T1 & T2 & T3 & T4 & T5 \\
\hline & $(0 \%)$ & $(7.5 \%)$ & $(15 \%)$ & $(22.5 \%)$ & $(30 \%)$ \\
\hline Maize & 61.00 & 55.50 & 51.00 & 46.00 & 42.30 \\
\hline Groundnut cake & 18.00 & 16.00 & 13.00 & 10.00 & 6.70 \\
\hline Cooked ALBSM & 0.00 & 7.50 & 15.00 & 22.50 & 30.00 \\
\hline Soya bean Full-fat & 10.00 & 10.00 & 10.00 & 10.00 & 10.00 \\
\hline Fish meal & 3.00 & 3.00 & 3.00 & 3.00 & 3.00 \\
\hline Wheat offal & 4.00 & 4.00 & 4.00 & 4.00 & 4.00 \\
\hline Bone meal & 3.00 & 3.00 & 3.00 & 3.00 & 3.00 \\
\hline Salt & 0.30 & 0.30 & 0.30 & 0.30 & 0.30 \\
\hline Lysine & 0.20 & 0.20 & 0.20 & 0.20 & 0.20 \\
\hline Methionine & 0.25 & 0.25 & 0.25 & 0.25 & 0.25 \\
\hline *Vitamin-mineral premix & 0.25 & 0.25 & 0.25 & 0.25 & 0.25 \\
\hline Total & 100 & 100 & 100 & 100 & 100 \\
\hline \multicolumn{6}{|l|}{ Calculated analysis (\%) } \\
\hline Crude protein & 21.00 & 21.00 & 21.00 & 21.00 & 21.00 \\
\hline Mebolizable Energy.(Kcal/kg) & 3016 & 3017 & 3018 & 3019 & 3023 \\
\hline Crude fibre & 5.72 & 3.85 & 4.62 & 5.39 & 6.15 \\
\hline Ether extract & 5.72 & 5.73 & 5.75 & 5.76 & 5.77 \\
\hline Ash & 3.05 & 3.19 & 3.33 & 3.47 & 3.60 \\
\hline $\mathrm{Ca}$ & 1.34 & 1.35 & 1.36 & 1.36 & 1.38 \\
\hline$P$ & 0.92 & 0.92 & 0.91 & 0.90 & 0.89 \\
\hline Lysine & 1.12 & 1.17 & 1.23 & 1.30 & 1.33 \\
\hline Methionine+ cystein & 0.56 & 0.60 & 0.64 & 0.68 & 0.72 \\
\hline Feed Cost $\mathbb{A} / \mathrm{kg}$ & 75.16 & 74.56 & 73.96 & 73.36 & 72.77 \\
\hline
\end{tabular}

*Biomix premix supplied the following per kg of diet: Vit A, 10000 i.u.; Vit D3 2000 i.u.; Vit E, 23mg; Vit K,2mg; Vit K2mg; B1 (thiamine) 1.8mg; Vit B2 (Riboflavin), 5.5mg; Vit B6 (Pyridoxine),3.0mg; Vit. B12, 0.015mg; Pantothenic acid, 7.5mg; Folic acid, $0.75 \mathrm{mg}$; Biotin, 0.06mg; Choline chloride, 300mg; Cobalt, 0.2mg; copper, 3mg; lodine, 1mg; Iron 20mg; manganese, 40mg; Selenium 0.2mg; Zinc, 30mg; Antioxidant, 1.25mg; M.E = Metabolisable Energy, ALBSM = African locust bean seed meal.

measured using a portable electric digital weighing scale. The weights of visceral organs weights were also expressed as percentage of body weights (Table 6 and 7 ).

\section{Data Analysis}

Data generated were subjected to Analysis of variance (ANOVA) using the general linear model of statistical analysis system (SAS, 2002). Statistical model used was:

$Y_{i j}=\mu+P i+e i j$

Where: $Y_{i j}=$ the $j^{\text {th }}$ observation of the $i^{\text {th }}$ processing methods by cooking of Locust bean seeds, $\mu=$ the overall estimate of the population mean, $\mathrm{P}_{\mathrm{i}}=$ the effect of the $i^{\text {th }}$ processing methods by cooking of African locust bean seeds and $\mathrm{E}_{\mathrm{ij}}=$ the random error.

\section{RESULTS AND DISCUSSION}

The performance of broiler at starter phase is presented in Table 4. The final body weights of chicks fed 0, 7.5, 15 and $22.5 \%$ cooked ALBSM diets were significantly (P>0.05) higher than those fed T5 $(30 \%$ cooked ALBSM diets). In terms of total weight gain, birds fed 7.5, 15 and $22.5 \%$ cooked ALBSM were similar. This observation contradicts the report of Damang (2007) who reported that cooking time applied to ALBS had no significant effect on final body weight and daily weight gain of birds.

This observation however agreed with work of Ogundipe (1980) who reported that broilers fed boiled soybean performed better than those fed raw soybean diets. This author also found that moist cooking resulted in better performance of broilers. The observation made in this study also agreed with the work of Amaefule and Obioha (2001) who reported better performance of 
Table 4. Performance of broiler chicken fed Cooked African Locust Bean Seed Meal Diets at starter phase.

\begin{tabular}{lccccccc}
\hline \multirow{2}{*}{ Parameters } & \multicolumn{7}{c}{ Inclusion level of cooked African locust bean seed meal } \\
\cline { 2 - 8 } & $\mathbf{0 \%}$ & $\mathbf{7 . 5 \%}$ & $\mathbf{1 5 . 0 0 \%}$ & $\mathbf{2 2 . 5 \%}$ & $\mathbf{3 0 \%}$ & $\mathbf{S E M}$ & $\mathbf{P}$ \\
\hline Initial body weight $(\mathrm{g})$ & 39.70 & 39.72 & 39.70 & 39.71 & 39.73 & 0.70 & 1.00 \\
Final body weight $(\mathrm{g})$ & $1127.00^{\mathrm{a}}$ & $1156.67^{\mathrm{a}}$ & $1194.33^{\mathrm{a}}$ & $1146.67^{\mathrm{a}}$ & $977.00^{\mathrm{b}}$ & 29.65 & 0.03 \\
Total weight gain $(\mathrm{g})$ & $1087.29^{\mathrm{bc}}$ & $1116.96^{\mathrm{ab}}$ & $1154.61^{\mathrm{a}}$ & $1106.96^{\mathrm{ab}}$ & $983.23^{\mathrm{c}}$ & 19.46 & 0.02 \\
Total feed intake $(\mathrm{g})$ & $1879.45^{\mathrm{ab}}$ & $1905.96^{\mathrm{a}}$ & $1889.25^{\mathrm{a}}$ & $1810.29^{\mathrm{b}}$ & $1853.51^{\mathrm{b}}$ & 9.75 & 0.04 \\
Feed conversion ratio & $1.72^{\mathrm{a}}$ & $1.70^{\mathrm{ab}}$ & $1.64^{\mathrm{b}}$ & $1.63^{\mathrm{b}}$ & $1.79^{\mathrm{a}}$ & 0.03 & 0.01 \\
Feed cost N/kg gain & $130.74^{\mathrm{a}}$ & $128.43^{\mathrm{a}}$ & $120.19^{\mathrm{b}}$ & $121.74^{\mathrm{b}}$ & $129.43^{\mathrm{a}}$ & 1.94 & 0.01 \\
Mortality rate (\%) & 4.45 & 6.45 & 4.22 & 9.11 & 4.89 & 0.28 & 0.58 \\
\hline
\end{tabular}

${ }^{a b c}$, mean with different superscripts on the same row are significantly different $(P<0.05), S E M$, Standard error of means, $P$, Probability value.

Table 5. Performance of broiler chicken fed Cooked African Locust Bean Seed Meal Diets at finisher phase.

\begin{tabular}{lccccccc}
\hline \multirow{2}{*}{ Parameters } & \multicolumn{7}{c}{ Inclusion level of cooked African locust bean seed meal } \\
\cline { 2 - 7 } & $\mathbf{0 \%}$ & $\mathbf{7 . 5 \%}$ & $\mathbf{1 5 . 0 0 \%}$ & $\mathbf{2 2 . 5 \%}$ & $\mathbf{3 0 \%}$ & $\mathbf{S E M}$ & $\mathbf{P}$ \\
\hline Initial body weight $(\mathrm{g})$ & 1607.11 & 1607.09 & 1607.12 & 1607.10 & 1607.13 & 0.54 & 0.88 \\
Final body weight $(\mathrm{g})$ & $2856.80^{\mathrm{a}}$ & $2966.68^{\mathrm{a}}$ & $2976.69^{\mathrm{a}}$ & $2786.87^{\mathrm{ab}}$ & $2585.75^{\mathrm{b}}$ & 61.57 & 0.01 \\
Total weight gain $(\mathrm{g})$ & $1249.74^{\mathrm{b}}$ & $1359.68^{\mathrm{a}}$ & $1369.70^{\mathrm{a}}$ & $1179.86^{\mathrm{b}}$ & $957.70^{\mathrm{c}}$ & 130.00 & 0.02 \\
Total feed intake $(\mathrm{g})$ & 3170.60 & 3391.40 & 3215.40 & 3215.40 & 3199.50 & 105.77 & 0.51 \\
Feed conversion ratio & 2.56 & 2.49 & 2.45 & 2.84 & 3.42 & 0.15 & 0.02 \\
Feed cost A/kg gain & $192.63^{\mathrm{b}}$ & $186.00^{\mathrm{ab}}$ & $181.3^{\mathrm{a}}$ & $208.47^{\mathrm{c}}$ & $239.27^{\mathrm{c}}$ & 13.12 & 0.01 \\
Mortality rate (\%) & 4.16 & 4.18 & 4.17 & 0.00 & 8.33 & 3.72 & 0.61 \\
\hline
\end{tabular}

${ }^{a b c}$, mean with different superscripts on the same row are significantly different $(P<0.05), S E M$, Standard error of means, $P$, Probability value.

broilers fed with boiled pigeon pea seed meal based diets compared to those fed diet containing raw pigeon pea seeds based diets. Total feed intake of birds was similar for birds fed 0, 7.5, 15, 22.5 and 30\% cooked ALBSM diets. This also disagreed with Damang (2007) who reported that cooking time had no significant effect on feed intake and on feed to gain ratio. The effects of cooked ALBSM on bird's performance during the starter phase showed depressed growth beyond the 15\% dietary level of inclusion. This also agreed with the finding Damang (2007) that $20 \%$ dietary inclusion level of ALBSM in the diets might be too high during the starter phase because of the level of the residual anti-nutritional factors in the cooked beans.

Table 5 showed the results of growth performance of broiler chickens fed cooked ALBSM at finisher phase. There were significant differences $(P<0.05)$ in the final body weight and total weight gain of birds. The final body weights were similar in chicks fed $0,7.5,15$ and 22.5 cooked ALBSM diets compared to those fed $30 \%$ cooked ALBSM diet. Birds fed 15\% CALBSM had the highest value final body weight $(2976.69 \mathrm{~g})$ compared to others. Total weight gains were significantly $(\mathrm{P}<0.05)$ higher and similar for birds fed $7.5 \%(1359.68 \mathrm{~g})$ and $15 \%(1369.70$ g) CALBSM diets. These were significantly $(P<0.05)$ better than other treatments. This agreed with Sarwatt et al. (1991) reported a decrease in the final body weight and a weight gain for broiler finishers as the level of lablab in their diet was increased. There was no significant difference $(P>0.05)$ in total feed intake. This observation disagrees with the report of Damang (2007) who stated that the optimum dietary inclusion of African locust bean seed meal for the finisher diet was $10 \%$. There was no significant difference $(P>0.05)$ in feed conversion ratio of the birds among the treatments. The feed cost per kilogram gain was similar and better for birds fed $15 \%$ and $22.5 \%$ cooked ALBSM diets ( $\mathrm{N} 186.00$ and $\mathrm{N} 181.32$ respectively) compared to others. This may be due to efficient utilization of the nutrients in these diets compared to other treatments. The results of this study agreed with the work of Doma (1998) who reported that the lower the feed conversion the better the diets in monogastric animals. There were no significant differences $(P>0.05)$ in the mortality rate of chickens among treatments.

The results of carcass analysis are presented in Table 6. Final live weight, carcass weight and dressing percentage were significantly $(P<0.05)$ influenced by 
Table 6. Carcass characteristics of broiler chicken fed cooked African Locust Bean Seed Meal Diets.

\begin{tabular}{lccccccc}
\hline Parameters & \multicolumn{7}{c}{ Inclusion level of cooked African locust bean seed meal } \\
\cline { 2 - 7 } & $\mathbf{0 \%}$ & $\mathbf{7 . 5 \%}$ & $\mathbf{1 5 . 0 0 \%}$ & $\mathbf{2 2 . 5 \%}$ & $\mathbf{3 0 \%}$ & $\mathbf{S E M}$ & $\mathbf{P}$ \\
\hline Final live weight (g) & $2840.23^{\mathrm{ab}}$ & $2951.22^{\mathrm{ab}}$ & $2980.05^{\mathrm{a}}$ & $22784.11^{\mathrm{b}}$ & $2570.03^{\mathrm{c}}$ & 4.00 & 0.01 \\
Carcass weight (g) & $1880.13^{\mathrm{b}}$ & $2020.14^{\mathrm{a}}$ & $2051.34^{\mathrm{a}}$ & $1920.03^{\mathrm{b}}$ & $1661.24^{\mathrm{c}}$ & 5.00 & 0.02 \\
Dressing percent (\%) & $70.95^{\mathrm{b}}$ & $71.34^{\mathrm{b}}$ & $73.20^{\mathrm{a}}$ & $71.42^{\mathrm{b}}$ & $69.88^{\mathrm{c}}$ & 0.48 & 0.01 \\
Breast muscle (\%) & $20.91^{\mathrm{b}}$ & $21.27^{\mathrm{b}}$ & $22.15^{\mathrm{a}}$ & $16.23^{\mathrm{b}}$ & $17.79^{\mathrm{ab}}$ & 1.71 & 0.03 \\
Thigh and Drum stick & $22.52^{\mathrm{a}}$ & $19.15^{\mathrm{ab}}$ & $19.84^{\mathrm{ab}}$ & $17.46^{\mathrm{b}}$ & $16.78^{\mathrm{b}}$ & 1.05 & 0.02 \\
Wings (\%) & $11.79^{\mathrm{a}}$ & $10.99^{\mathrm{ab}}$ & $9.88^{\mathrm{ab}}$ & $8.92^{\mathrm{b}}$ & $8.79^{\mathrm{b}}$ & 0.80 & 0.03 \\
Neck weight (\%) & 7.33 & 7.40 & 7.41 & 7.35 & 7.40 & 0.07 & 0.45 \\
Back weight (\%) & 18.21 & 17.71 & 17.32 & 16.57 & 15.61 & 1.72 & 0.51 \\
Abdominal fat (\%) & 1.44 & 1.62 & 1.21 & 1.24 & 1.33 & 0.18 & 0.62 \\
\hline
\end{tabular}

abc, means with different superscripts on the same row are significantly different $(P<0.05)$, SEM, Standard error of means, NS, Not Significant, $\mathbf{P}$, Probability value, ${ }^{*}$ Carcass weight expressed as $\%$ live weight.

Table 7. Organs and gut weights of broiler chickens fed cooked African Locust Bean Seed Meal Diets.

\begin{tabular}{lccccccc}
\hline Parameters & \multicolumn{7}{c}{ Inclusion level of cooked African locust bean seed meal } \\
\cline { 2 - 8 } & $\mathbf{0 \%}$ & $\mathbf{7 . 5 \%}$ & $\mathbf{1 5 . 0 0 \%}$ & $\mathbf{2 2 . 5 \%}$ & $\mathbf{3 0 \%}$ & $\mathbf{S E M}$ & $\mathbf{P}$ \\
\hline Heart (\%) & 0.52 & 0.44 & 0.45 & 0.43 & 0.44 & 0.03 & 0.22 \\
Lungs (\%) & 0.52 & 0.46 & 0.46 & 0.48 & 0.46 & 0.03 & 0.15 \\
Liver (\%) & $1.85^{\mathrm{b}}$ & $2.18^{\mathrm{ab}}$ & $2.01^{\mathrm{ab}}$ & $2.27^{\mathrm{a}}$ & $2.08^{\mathrm{ab}}$ & 0.12 & 0.01 \\
Pancreas (\%) & 0.26 & 0.23 & 0.28 & 0.27 & 0.28 & 0.02 & 0.09 \\
Kidney (\%) & 0.35 & 0.34 & 0.32 & 0.31 & 0.34 & 0.03 & 0.94 \\
Crop (\%) & 0.10 & 0.11 & 0.11 & 0.10 & 0.11 & 0.02 & 0.66 \\
Proventriculus (\%) & 0.24 & 0.22 & 0.23 & 0.22 & 0.23 & 0.03 & 0.08 \\
Gizzard (\%) & $2.90^{\mathrm{a}}$ & $2.52^{\mathrm{c}}$ & $2.62^{\mathrm{b}}$ & $2.52^{\mathrm{b}}$ & $2.41^{\mathrm{c}}$ & 0.12 & 0.02 \\
Small intestine weight (\%) & $2.72^{\mathrm{a}}$ & $1.88^{\mathrm{b}}$ & $2.16^{\mathrm{b}}$ & $1.12^{\mathrm{c}}$ & $2.04^{\mathrm{b}}$ & 0.15 & 0.03 \\
Small intestine length (cm) & 311.22 & 295.77 & 334.00 & 324.01 & 314.56 & 21.06 & 0.78 \\
Large intestine weight (\%) & 1.67 & 1.52 & 1.49 & 1.26 & 1.35 & 0.09 & 0.76 \\
Large intestine length (cm) & 37.02 & 35.08 & 34.52 & 36.54 & 34.97 & 0.79 & 0.87 \\
\hline
\end{tabular}

abc, means with different superscripts on the same row are significantly different $(P<0.05)$, SEM, Standard error of means, NS, Not Significant, $\mathbf{P}$, Probability value.

dietary treatments. The final live weights were similar and higher at $0,7.5$ and $15 \%$ cooked ALBSM diets having 2840.23, 2951.22 and $2980.05 \mathrm{~g}$ respectively, but lowest value was recorded for birds fed $30 \%$ cooked ALBSM diet. Carcass weight was higher for diet 2 and 3 (2020.14 and $2051.34 \mathrm{~g}$ respectively) and lowest for those fed T1 and T5 with values of 1880.13 and $1661.24 \mathrm{~g}$ respectively. Birds fed 15\% cooked ALBSM diet had significantly $\quad(P<0.05)$ higher dressing percentage $(73.20 \%)$ compared to other treatments. The dressing percentage was observed better for birds fed 15\% ALBSM diet. These results agreed with Omeje (1999) and Kaankuka et al. (2000) who reported that processing improved the utilization of proteins and energy contained in legumes. It has been shown that as the protein level increased in the food consumed; it leads to better muscle deposition and production of leaner carcass (Hill and Dansky 1954). Breast muscles, thigh and drumstick followed the same pattern. The breast muscle, thigh and drum stick were significantly $(P<0.05)$ affected by the dietary treatments. T3 had higher percentage of breast muscles $(22.15 \%)$ compared to others. The thigh and breast muscle showed significant differences $(P<0.05)$ among the treatments. Wings weight were significantly $(\mathrm{P}<0.05)$ different with highest value in $\mathrm{T} 1(11.79 \%)$ and lowest value in T4 (8.79\%), while broilers fed $30 \%$ ALBSM diet had the lowest value (8.79\%). Omeje (1999) found that cooking had significant effect on the antinutritional factors in grain legumes by reducing its effects and allowing better utilization of nutrients in the body. This is not in agreement with Damang (2007) who stated that cooking time had no significant effect on the dressing 
percentage, gizzard, intestinal and abdominal fat and kidney weights. There were no significant differences in the values for neck, back weights and abdominal fat weights among treatments.

The effects of cooked African locust bean diets on the organs and gut weight are presented in Table 7 . The results showed no significant differences $(P>0.05)$ for most of the organs (heart, lungs, pancreas and kidney). The gut weights (crop, proventriculus, small intestinal weight and length, large intestine weight and length) were also not significantly $(P>0.05)$ affected by the treatments. However, the liver was significantly $(P<0.05)$ affected by the dietary treatments. Diets $2,3,4$, and 5 gave the highest percentages of liver weight having values 2.18, $2.01,2.27$ and $2.08 \%$ respectively. Heavier weight of organs could be an indication of hypertrophy (Pond, 1989). There were significant differences $(P<0.05)$ in the Gizzard and small intestine weights. Broiler chicken fed the control diet had the highest weights of gizzard weight $(2.90 \%)$, while diet 5 had the lowest value $2.41 \%$. Similarly, small intestine weight was higher in diet 1 $(2.72 \%)$ and lowest for diet 4 (1.12\%). Abeke (2005) reported Lablab seed should be well cooked to be properly utilized without posing any danger to the health of chicks

\section{CONCLUSION}

Study indicates that African locust bean cooked for 4 hours can be included in the diets of broiler chicken up to $15 \%$ without any adverse effect on the growth, organs weights and carcass characteristics.

\section{CONFLICT OF INTEREST}

The authors declare that they have no conflict of interest.

\section{REFERENCES}

AOAC (1990). Official Methods of Analysis, Association of official Analytical Chemist, Washington DC. Pp. 423-858.

Abeke, F.O. (2005). Evaluation of the nutritive value of Lablab purpreus in replacing groundnut cake in poultry diets. Unpublished Ph.D. Dissertation Department of Animal Science A.B.U. Zaria, Nigeria. Pp. 74-140.

Abeke, F.O. (2008). Fibre in poultry diets concerns and options, In: Proceeding of the $33^{\text {rd }}$ Annual conference of the Nigerian Society for Animal Production held at the College of Agricultural Sciences, Olabisi Onabanjo University, Ayetoro, Ogun state, Nigeria, p. 409.

Adebowale, K. O., \& Lawal, O. S. (2004). Comparative study of the functional properties of Bambara groundnut (Voudzea subterranean), Jack bean (Canavalia ensiformis) and Mucuna bean (Mucuna pruperien). Food Research International, 37, 355-365.
Amaefule, K. U., \& Obioha, F. C. (2001) Performance and nutrient utilization of broiler starters fed diets containing raw boiled or dehulled pigeon pea seeds (Cajanus cajan). Nigerian Journal of Animal Production, 28(1), 31-39.

Bamgbose, A. M., Isah, O. A., Sobayo, R. A., Oso, A. O., Okeke, E. N., \& Alonge, A.S. (2011). Utilization of bovine Blood rumen digesta mixture based diets by cockerels chicks. In:Proceeding of $36^{\text {th }}$ Annual conference of the Nigerian Society for Animal Production, $13^{\text {th }}-16 \mathrm{t}$ march, Abuja. Pp. 391-394.

Campbell-platt, G. (1980). African locust bean and its West African fermented seeds in Nigeria. Journal of Agricultural Food Chemistry. 34, 189-192.

Dafwang, I., Ikani, E. J., Chikwendu, D. O., Adesehinwa, A. O. K., Annate, A. I., \& Iwuayanwu, I.E.J. (2001). An assessment of adoption of non-conventional feedstuffs. Poultry and Rabbit Research, (3), 3-5.

Damang, P. J. (2007). Nutritional evaluation of African locust bean (Parkia species) seeds in the diets of Broiler chicken. M.Sc. Thesis Unpublished, submitted to the Department of Animal Science, Ahmadu Bello University Zariia, Nigeria. Pp. 92-97.

Dike, E. N., \& Odunfa, S. A. (2003). Microbiology and biochemical evaluation of fermented soya bean products (Soya dawadawa). Journal of Food Science Technology, 40, 606-610.

Doma, U. D. (1998). Utilization of cowpea shell and maize cobs as sources of fibre for rabbits. A .M.Sc. Thesis report Submitted to Abubakar Tafawa Balewa University, Bauchi. Pp. 63-67.

Duru, S. (2010).Effects of different type of rice offal with or without enzyme supplementation on the performance of broiler chickens. A PhD. Thesis, Ahmad Bello University Zaria

Hill, F. W., \& Dansky, K. W. (1954). Studies on the energy requirement of chickens and feed consumption. Poultry Science Journal, 11, 112-1189.

Kaankuka, F. G., Balogun, T. F., \& Yaakugh, I. D. I. (2000). Effect of duration of cooking of full-fat soyabeans on dry matter digestibility and energy utilization by young pigs. $30^{\mathrm{TH}}$ Proceeding of Annual conference of Nigerian Society for Animal production (NSAP). Pp. 191-193.

Kehinde. A. S., Babatude, T. O., Ayoola, O. A., \& Temowo, O. O. (2006). Effect of different level of protein on the growth performance characteristics of broiler chicks. In: proceedings $31^{\text {st }}$ Annual Conference of the Nigerian Society for Animal Production. $12^{\text {th }}-15^{\text {th }}$ March, Bayero University kano, Nigeria, Pp. 325-237.

Longe, O. G. (2006). Poultry: Treasure in chest, an inaugural lecture delivered at University of Ibadan Nigeria. Pp. 1-10.

National Research Council (NRC) (1994). Nutreit Requirement of Domestic Animal. Nutreints Requirements of Poutry 5th edition. National Academic Press. Washiigton D.C. Pp. 100120.

Ogundipe, S. O. (1980). Effects of Boiling / Roasting on subsequent utilization of soyabean by chicken. PhD. Dissertation, Michigan state University, East Lansing Mich. U.S.A.

Ogundipe, S. O. (1987). Non-conventional poultry feedstuffs from research to practice; A paper presented at the poultry Farmers Workshop, N.A.E.R.L.S. at 
Ahmadu Bello University Zaria. Pp. 1-10.

Olofin, E. A., Nabegu, A. B., \& Dambazau, A. M. (2008).Wudil within Kano region; A geographical synthesis, $1^{\text {st }}$ edition, Adamu joji publishers. Kano State, Nigeria, Pp. 134-138.

Olomu, J. M. (2011). Monogastric Animal Nutrition; Principles and Practice. $2^{\text {nd }}$ Edition University of Benin, Jackson publishers, Nigeria. Pp. 160-165.

Omeje, S. I. (1999). Issues in Animal Science, Raykennedy Scientific Publication Enugu, Nigeria, Pp 31-34.

Oyenuga, V. A. (1968). Nigeria's food and feeding stuffs lbadan, university press.
Pond, R. T. (1989).Toxic factors and problems in animal organs. Journal of Nutrition, 117, 834-900.

Sarwatt, S. V., Katunle, A. M., \& Lugend, A. J. H. (1991). Effects of substituting dolichos bean meal for soyabean meal on the performance of broiler chickens. Livestock Resource for Rural Development, 3(1), 143-150.

SAS (2002) Statistical Analysis System User Guide for Statistics Version 10. SAS institute Inc, Carolina, U.S.A. 